\title{
Niezapomniany rok 1942
}

\author{
Ewa Weinberg
}

\begin{abstract}
Abstrakt: Świadectwo Ewy Weinberg dotyczy wywózki obywateli polskich do ZSRR latem 1940 roku i przeżyć roku 1942. Po zawarciu paktu Sikorski-Majski 31 lipca 1941 roku, na wieść o tworzeniu armii gen. Władysława Andersa deportowani przedostają się z Syberii do Samarkandy w Uzbekistanie (ZSRR). Na miejscu okazuje się, że we wspólnocie uchodźców nie obowiązuje kategoria obywatelstwa. Autorka opisuje praktyki antysemickie, a także dyskryminację chrześcijan innych niż rzymscy katolicy, jako zjawisko systemowe i prawomocne z punktu widzenia większościowego modelu kultury polskiej. Bliscy i znajomi autorki, inteligencja polska, przy próbie zajęcia miejsca w pociągu do Teheranu słyszą pytanie: „Taki naród handlowy, a nie ma bodaj obrączek?". W efekcie część wagonów odjeżdża pusta, pozostawiając na pastwę klimatu, głodu, chorób i terroru stalinowskiego obywateli polskich zakwalifikowanych jako "gudłaje i kacapy".

Wyrażenia kluczowe: wywózki radzieckie, Syberia, Samarkanda (Uzbekistan), Teheran (Persja/Iran), armia Andersa (7 Dywizja), antysemityzm, wykluczenie, dyskryminacja, biskup Józef Gawlina, Leopold Okulicki, rodzina Weinbergów, rodzina Weindlingów, rodzina Zyssów, Poleszucy
\end{abstract}

„Pożiwiosz - priwykniesz; nie priwykniesz - podochniesz” - tę powszechną sowiecką maksymę powtarzali nam nieustannie enkawudyści (zdaniem zesłańców, NKWD był to skrót od „nie wiem, kiedy wrócę do domu”) na posiołku Faniernym, 8 km od miasteczka Tawda, a jakieś $800 \mathrm{~km}$ na północ od Swierdłowska [dzis. Jekaterynburg] ${ }^{1}$. Znaleźliśmy się tam w lipcu 1940 roku wskutek wielkiej fali wywózek z tzw. Zachodniej Ukrainy, w naszym przypadku z Czortkowa, gdzie byliśmy uchodźcami z Katowic. My - to moja mama, doktor Anna Weinberg, lat 39, dermatolog, zatrudniona w zduńskiej brygadzie przy budowie pieców, mój 48-letni ojciec, doktor Henryk Weinberg, położnik, kiepski drwal przy wyrębie tajgi, i ja, uczennica 2 klasy miejscowej szkoły.

Wydawało się, że hen po Swierdłowsk nie ma ani jednej naprawdę wolnej duszy. „Zona” była wszędzie, nawet nasi pilnowacze nie mieli prawa opuszczania tego obszaru. W szkole wraz z innymi dziećmi deklamowałam wierszyki na cześć Stalina. Nigdy, przenigdy nie pytałam innych, skąd pochodzą czy dlaczego tu są - to pierwsza wiedza o świecie, jaką się nabywa wśród wywiezionych.

Żyliśmy w środku tajgi, która dostarczała jagód czy grzybów. Na kartki chlebowe aż do wybuchu niemiecko-sowieckiej wojny dostawaliśmy po 800 gram na pracującego i po 450 gram na członka rodziny. Nie było na razie głodno, tyle że dieta była bezbiałkowa i praktycznie pozbawiona cukru. Za niewykonanie normy karano obcięciem kartki chlebowej o ileś tam. Młodzież pracująca z moim ojcem dbała, żeby jego oczywiste braki w zawodzie drwala ukryć przed władzą. Ojciec pochodził z Kalisza, maturę rosyjską zdawał w roku jubileuszu domu Romanowów (1913), więc od początku naszego pobytu

1 Dopiski w nawiasach kwadratowych pochodzą od Redakcji. 
tłumaczył, czytał ludziom papiery, pomagał w kontaktach z komendantem, a przede wszystkim uczył mnie i inne dzieci rosyjskich liter.

Siostra ojca ze swoją rodziną znalazła się w getcie warszawskim i choć to wyobrazić sobie trudno, rodzice z tej przysłowiowej głodnej Syberii posyłali im jakieś mizerne paczki z kaszą i sucharami aż do wybuchu wojny niemiecko-sowieckiej...

W ramach „przywykania” dorośli sadzili kartofle na mikroskopijnych działkach przyzagrodowych, a dzieci po zakończeniu roku szkolnego, bez jakiegokolwiek nadzoru ze strony dorosłych (dorośli pracowali przeszło 12 godzin) zajmowały się czystym chuligaństwem, np. wyżeraniem niedojrzałego grochu u przesiedlonych Niemców powołżańskich [nadwołżańskich]. Niemcy byli na posiołku już od kilku lat, byli pracowici, zagospodarowani, mieli jakieś kury, jakieś ogródki i umierali ze strachu, że lada chwila mogą ich wywieźć hen na Magadan - wystrzegali się kontaktów z innymi wywiezionymi. U nich, w ścisłej tajemnicy, mama wymieniała swoje bluzki za jakieś mleko, a kiedy zachorowałam na odrę, to nawet dostałam jajko, niezapomniany smakołyk.

Pamiętam dzień, w którym ogłoszono, że Hitler napadł wiarołomnie na Związek Radziecki. Było to chyba koło 1 lipca, panował dziki upał, komary żarły bezlitośnie, a dorośli mieli wręcz dreszcze ze strachu. Wtedy nie rozumiałam, jak bardzo pogorszył się nasz status. Z polskich ciemiężycieli Ukrainy Zachodniej my, urodzeni na terenie Generalnej Guberni, staliśmy się Niemcami! Wrogiem! Normy chlebowe spadły na łeb, na szyję, konwój odprowadzający dorosłych na 12 godzin do tajgi i na spław belek zrobił się jeszcze bardziej ordynarny, choć ci szeregowi enkawudyści byli na ogół analfabetami i co to takiego GG, i tak nie wiedzieli... Zaczęli natomiast obawiać się frontu.

Grozą wiało gdzieś do końca sierpnia lub do początku września. Nie było wiadomo, czy „warto” iść do szkoły, czy zaraz wyślą nas dalej w głąb tundry, czy za krąg polarny. I nagle... chyba na początku września nowe zebranie, na którym komendant ogłasza, że jesteśmy wolni, że Towariszcz Stalin pozwala nam opuścić miejsce zesłania, nawet od zaraz, że odtąd jesteśmy sojusznikami, że dostaniemy putiowki, czyli pozwolenie na skorzystanie z pociągu, i nawet wolno nam będzie zabrać kartki chlebowe...

Nie potrafię sobie przypomnieć, kiedy i jak dowiedzieliśmy się o umowie Sikorskiego i o powstawaniu polskiego wojska w Buzułuku. Wszyscy chcieli uciec z północy czym prędzej, przed zimą, która już się niebezpiecznie zbliżała, a myśl o poprzedniej, przy braku ciepłej odzieży, niedożywieniu i groźnych odmrożeniach, była właściwie wszechobecna. Śnieg w tych okolicach zaczyna padać we wrześniu.

Mama zamartwiała się o swoich rodziców, pozostawionych w Krakowie. Jedna z jej sióstr została, niewywieziona, we Lwowie (zginęła później na Majdanku), a najstarsza wraz z mężem i córką była zesłana gdzieś pod Archangielsk. Kiedy pojawiła się możliwość spotkania z bodaj częścią rodziny, przy całkowitej niepewności, co może się w nieobjętej dla ludzkiego oka rzeczywistości zdarzyć, rodzice postanowili odczekać do ich przyjazdu na „nasz” posiołek. 
Ciocia Elza miała chyba 43-44 lata, była z wykształcenia pianistką, ale całe swoje życie zajmowała się domem. Jej mąż, wuj Zygmunt, był lekarzem internistą, sporo chyba starszym od niej, ponieważ zdążył dosłużyć się stopnia kapitana w wojsku austriackim w czasie pierwszej wojny światowej. Ich córka Olga miała 15 lat, kiedy połączonymi siłami udaliśmy się na południe, byle szybciej, byle do ciepła.

To, co pamiętam najlepiej z tej podróży, to toboły. Mieliśmy jeszcze jakieś walizy. Ale prawdziwe skarby mieściły się w tobołach. Pamiętam, że w Czelabińsku można było wykupić cały należny chleb kartkowy do końca miesiąca i ten chleb spowity był w koc i pilnie strzeżony, tzn. umieszczany pod głową tego, kto zdołał umieścić się na półce w pociągu. Dalej trasa biegła do Czkałowska, pociąg osobowy skończył bieg tam właśnie, dalej były już tiepłuszki, czyli wagony towarowe. Chyba właśnie na tym odcinku - rzekłoby się „odcinie" przy rosyjskich odległościach - dowiedzieliśmy się o Buzułuku i tworzącej się tam brygadzie wojska polskiego. Coraz więcej wynędzniałych postaci w strzępach fufajek, w onucach bez butów, przyłączało się do tłumów obozujących w drodze na południe. Żebrali o chleb, niektórzy byli już w drodze od tygodni. Chyba od nich nasi dorośli dowiedzieli się, że Buzułuk już nieaktualny, że korpus tworzy się w okolicach Samarkandy.

Wojna była już wszechobecna - pociągów ubyło gwałtownie wskutek rekwizycji, uchodźcy z Ukrainy i Białorusi, tzn. kobiety i dzieci leżały pokotem na każdej stacyjce, czekając na jakąś możliwość transportu, mężczyzn bez końca legitymowano, jedzenie znikło, nawet o przysłowiowy kipiatok ('wrzątek') było trudno bez opłaty. Pieniądze zresztą za mojej pamięci nie służyły już w tym czasie do niczego, handel był wyłącznie wymienny. Podczas licznych przestojów mijały nas długie pociągi towarowe z rannymi. Rozlegały się z nich jęki i przekleństwa...

Na razie wszyscy cieszyli się z tego, że cieplej, że tępienie wszy w warunkach podróży ograniczało się do cieńszej odzieży. Po jakichś dwóch tygodniach znaleźliśmy się w tłumie przydworcowym kompensirowocznej stancji Ursatewskaja. Takie stacje to jeden z szatańskich pomysłów władzy radzieckiej. Miały służyć do sprawdzania biletów, a może tylko do kolejnych szykan. Wydawało się, że stamtąd do Samarkandy trzeba będzie pójść pieszo, dalszego transportu już nie było. Po dwóch-trzech dniach oczekiwania, kiedy z chleba już nic nie zostało, ojciec trafił na jakiegoś Rosjanina, który również chciał do Samarkandy i twierdził, że za stacją stoi sprawna lokomotywa i kilka wagonów, trzeba tylko zebrać na większą wódkę dla konduktora. Nie wiem, skąd pojawiła się owa wódka, ale w pewnej chwili ojciec poderwał naszą grupę okrzykiem: szybko, jest wagon! Towarowe wagony radzieckie były bardzo wysokie, bez stopni, gramolenie się do nich wymagało pomocy co silniejszych współpasażerów.

Moja niesłychanie krótkowzroczna mama, wrzucona na podłogę wagonu, zaprotestowała: ależ tu pełno mrówek! Poirytowany ojciec, rad, że wszyscy jesteśmy w środku bez utraty bagażu i nieokradzeni przy „podsadzaniu”, wybuchł: „Czy naprawdę nie widzisz, że to wszy?". Po tylu latach wciąż widzę tę scenę: mój wuj, który wkłada swój cwikier 
i weryfikuje „diagnozę” taty, i moje z kuzynką próby zadeptania obrzydlistwa, a cała podłoga jest już zasiedlona przez współpodróżnych całkowicie obojętnych na coś tak powszedniego.

W Samarkandzie znaleźliśmy się chyba pod sam koniec października 1941 roku. Wiem, że było ciepło, że na bazarze były prawdziwe owoce i jarzyny, na mnie największe wrażenie zrobiły długie warkocze, plecione z suszonych melonów. Słodkie! Pyszne! I bez kartek...

Zamieszkaliśmy na starym mieście - nowe było chyba niedostępne dla obcokrajowców. Była to gliniana jednoizbowa kibitka przy ulicy Bulungurskiej, z klepiskiem zmywanym miotłą, później z cudem zdobytą tzw. kozą do ogrzewania, choć wydawało się, że jesteśmy w ciepłym raju. Do ogrzewania? Niebawem rola kozy spuchła do najważniejszego elementu naszego bytowania w Samarkandzie. Ale o tym będzie nieco później, na razie ojciec i wujek niezwłocznie rozpoczęli poszukiwania owego Graala, czyli polskiego korpusu - nazwisko [gen. Władysława] Andersa jeszcze się nie przewijało, to miał być korpus [gen. Władysława] Sikorskiego. Delegatura rządu londyńskiego pojawiła się chyba w grudniu, tymczasem trzeba było zarejestrować się, propisat'sja w milicji, żeby mieć choć szansę na kartki chlebowe. Nie wiem, ilu mieszkańców Samarkanda liczyła w czasach pokojowych, jesienią 1941 roku uchodźców były setki tysięcy, ludzie spali na ulicy, usiłowali wcisnąć się pod dachy na bazarze, leżeli na różnych schodach, zganiani przez milicję. Zaczęły się deszcze, a wraz z nimi powszechna epidemia tyfusu, który zabijał błyskawicznie głodujących bezdomnych.

W Samarkandzie pojawili się ewakuowani z oblężonego Leningradu [dzis. Sankt Petersburg] pracownicy Akademii Sztuk Pięknych. Umieszczono ich w Registanie, jednym z najpiękniejszych zabytków sztuki islamskiej. Byli zagłodzeni i wymagali opieki lekarskiej, zasypiali tylko z przydziałowym chlebem pod głową, ale o swoich doświadczeniach milczeli. Rodzice oboje zostali zatrudnieni jako lekarze, właściwie trochę przez przypadek - mianowicie pani rektorowa Nelli Adamowna Faworska była rada polskim lekarzom, albowiem „mojemu papie toże goworili «pan»". Ryż wypisywano im na receptę, dostawali też chleb bez kartek. Rodzice mieli prawo wypisywania sobie 125 gram ryżu na tydzień...

Wszystko, co mogło być zmilitaryzowane, zostało zmilitaryzowane, koleje były już wyłącznie do dyspozycji wojska, szalała szpiegomania, nikt nie wiedział, czy na przykład o Stalingradzie wolno mówić głośno, czy „przyznanie się” do chęci służby w polskim korpusie nie okaże się jakąś pułapką, czy nie wcielą siłą do Armii Czerwonej...

Wreszcie pojawiła się komisja rekrutacyjna, w nowym mieście, odległym o $7 \mathrm{~km}$ od starego. Chodziło się oczywiście piechotą, z obuwiem w gęstym błocku były kłopoty, a tych spacerów ojciec i wujek odbyli wiele. Komisja spojrzała na dokumenty, Weinberg i Weindling, i... orzekła, że na razie jednostki nie ma jeszcze, że może będą na jakiejś liście kandydatów, ale przyślą zawiadomienie w późniejszym terminie, kiedy lekarze może będą potrzebni. Czy mogą wciągnąć na jakąś listę zapomóg? Nie, nie mogą. 
Tyfus i choroby głodowe pochłaniały coraz więcej ofiar. Na ulicy leżały trupy w błocie pod rozmoczonymi strzępami gazet - porządne gazety były na wagę złota do skręcania machorki. A w domu co wieczór ciocia Elza z mamą i nami, dwiema dziewczynkami, szukała wszy na każdej sztuce odzieży, po czym każdy szew był prasowany gorącym żelazkiem na węgiel drzewny. Jeśli wspomniałam o naszym adresie, to dlatego, że było to niedaleko od bazaru, a kupowanie węgla drzewnego i buraków cukrowych, podstawy wyżywienia, należało do obowiązków Olgi i moich. Byłyśmy na tyle małe, że mogłyśmy przejść, nie ocierając się o nikogo, a ciotka sprawdzała nas i tak od stóp do głów po każdej wycieczce. Do szkoły nie chodził chyba nikt spośród uchodźców ukraińskich, białoruskich czy polskich - nie wiem nawet, czy bez nieodzownej propiski było to możliwe. Byłyśmy zresztą bardzo zajęte, tylko ktoś, kto przeżył owe czasy, zdaje sobie sprawę, jak pracochłonna jest ciągła pustka w brzuchu, napełnianym kaszą na wodzie i pieczonymi burakami.

Najdziwniejsze, że trupy mijałyśmy zupełnie bez wrażenia, czasem trzeba było je przeskoczyć pod apteką na Pendzykienckiej. A apteka stała się w styczniu 1942 roku niezwykle ważna - wuj Zygmunt zachorował na tyfus. Miał ponad 40 stopni, z leków dostępna była aspiryna, a w aptece dominowało coś, co nazywało się „belladonna z salolem”. $\mathrm{Na}$ czarnym rynku rodzice płacili obrączkami za sulfidynę, sowiecki lek-cud z grupy sulfamidów, chroniący przed zapaleniem płuc. W noc kryzysu siedzieliśmy wszyscy pięcioro przy pryczy wujka, wydawało się, że nie doczeka ranka. Doczekał, ożył, tylko był tak chudy, że nie mógł siedzieć, skórę na pośladkach przebijały kości. Tymczasem z tyfusem zlegt mój ojciec, po niewielu dniach straszliwej gorączki pojawiło się obustronne zapalenie płuc. Wszystko, co nadawało się jeszcze do sprzedaży/wymiany, zostało zużyte na leki, w końcowej fazie mama robiła zastrzyki ze zdobytej kamfory prosto do serca. Ojciec przetrwał, jego serce pozostało bezpowrotnie nadwyrężone.

A obok tego gara do gotowania bielizny na kozie, obok dwóch prycz, na których kolejno chorowali wujek i tata, rozpędzała się polska historia - powstała 7 Dywizja w miasteczku Kermine [w obwodzie bucharskim, dzis. Nawoi], odległym od Samarkandy o kilka godzin koleją. Plotki wśród polskich uchodźców utrzymywały, że nadeszły transporty brytyjskie, że jest umundurowanie, konserwy i szpitale polowe, zaopatrzone w lekarstwa. Moja zdesperowana mama zgłosiła się kolejny raz do komisji rekrutacyjnej, błagając o leki, a przy okazji wspomniała, że wuj jest po tyfusie i wymaga odżywienia. Wynik był dość niespodziewany - dla ojca nie udało się uzyskać niczego, natomiast lekarz, który był już po tyfusie, był niezwykle cennym nabytkiem dla wojska, gdzie tyfus powalił ze $30 \%$ połagrowych nieszczęśników.

Na początku marca, było już całkiem ciepło, na podwórko przed naszą chatą wkroczyło czterech chłopaków w brytyjskich battledressach z noszami. Z plecaka wyjęli mundur oficerski i wyjaśnili, że polecono im dostarczyć kapitana Weindlinga do jednostki wojskowej w Kermine. Mama i ciotka musiały pomóc straszliwie osłabionemu wujowi wkładać ów mundur rozmiarów godnych brytyjskiej gwardii. Wydawało się, że wuj wpadnie do niego do środka przez otwór kołnierza. Przy wszystkich udrękach, chorym ojcu, niepewności, 
co dalej z pozostałą piątką, pamiętam nieopisany komizm tej sceny, kiedy to nasz biedny, chudy Szwejk był na noszach transportowany do wojska. Obie nasze mamy śmiały się przez łzy, tylko Olga, uwielbiająca ojca, miała ten śmiech za złe. Po kilku ciężkich tygodniach przyszła wiadomość od tzw. Delegatury, że ciocia Elza z córką mają się udać do Kermine, skąd rodziny wojskowe zostaną ewakuowane za granicę. Moi rodzice nie byli uznani za rodzinę wojskową, wydawało się, że ojciec nie przeżyje tyfusu, zostaliśmy w trójkę w Samarkandzie.

Rzeczywiście pod koniec marca rodziny wojskowe i jakieś naprędce zorganizowane sierocińce odjechały z Kermine do Teheranu, a rodzice odetchnęli z ulgą - to nie była prowokacja, nie pognano ich w przeciwną stronę. Ojciec poprawił się na tyle, że można było się starać o pozwolenie na pociąg (putiowkę) do Kermine, do wojska, w końcu na razie ojcu nikt jasno nie odmówit. Tobołów było już całkiem niewiele, wszystko, co się nadawało do wymiany, pochłonęły leki i wyżywienie dwóch ciężko chorych.

Kermine to była maleńka stacyjka kolejowa, wokół pustynia, samo osiedle o tej nazwie było oddalone o około $8 \mathrm{~km}$, tam mieściło się dowództwo 7 Dywizji, szpital polowy i instytucje radzieckie z wojenkomatem, czyli komendą uzupełnień, na czele. Koło stacji było kilkadziesiąt gospodarstw uzbeckich, tylko niektóre miały studnie w obejściu, woda była głęboko. Nie wiem, jakie pacyfikacje przetoczyły się przez ten rejon, ale rozkaz tow. Stalina o wprowadzeniu monokultury bawełnianej został wykonany dosłownie. Za hodowlę ryżu groziła kara śmierci, bez śladu znikły owoce granatów jako rzekomy symbol Allaha. Przy drodze do miasteczka przetrwały smętne drzewka morelowe, z których rabowaliśmy później malutkie kwaśne owocki.

Powitał nas wuj Zygmunt przy stacji, z uzbieranymi dla nas brytyjskimi konserwami, powiedział, że mieszka w szpitalu, a my musimy znaleźć jakiś dach nad głową, bo dalsze transporty do Teheranu nie będą tak zaraz. Nie pamiętam, jak spotkaliśmy się z przyjaciółmi rodziców, rodziną Zyssów, którzy pojawili się w Kermine jako rodzina wojskowa lekarza kapitana Adama Zyssa, brata pana Bernarda. Żona i syn kapitana odjechali pierwszym transportem do Teheranu, podobnie jak moja ciocia Elza z córką. Tłumy polskich uchodźców obozowały wokół stacji, wokół wojskowych baraków, wokół nieczynnej fabryki oddzielającej nasiona od zebranej bawełny - byle tylko znaleźć choć odrobinę cienia pod koniec kwietnia było już koło 50 stopni. Wśród tych najbiedniejszych nie było chyba wcale całkiem malutkich dzieci, myślę, że nie przetrzymały dwóch syberyjskich zim.

Zarówno ojciec, jak i pan Bernard Zyss, mówili znakomicie po rosyjsku, co wywoływało w Uzbekach podejrzliwą niechęć, z czego nie zdawaliśmy sobie sprawy. Jednak po rundzie do pobliskich gospodarstw i wyjaśnieniu, że ojciec jest lekarzem - prawdziwym, a nie feldczerom - zgodzili się nas umieścić w stajence osła. Osła wyprowadzono, klepisko zostało zmyte wodą, na ile się dało, gospodarze wstawili dwie prycze i zamieszkaliśmy w szóstkę w tym pomieszczeniu. Gotowanie wody odbywało się na kilku cegłach przed wejściem, a wodę gotowało się maniakalnie, nie wolno było wypić kropli surowej. 
Opał zbieraliśmy my, to znaczy jedenastoletni Witek Zyss i ja, głównie były to piekielnie kłujące krzaczki o nazwie medwez’ja koliuczka, ale kradliśmy też bezlitośnie jakieś gałązki czy tekturowe pudła od konserw pod polskimi namiotami gospodarczymi. Działo się to w ostrej rywalizacji z całymi tłumami biedniejszych od nas rodzin wojskowych, które obozowały bez dachu nad głową. Przede wszystkim były to rodziny, które zostały wywiezione w lutym 1940 roku i w czasie aż dwóch zim na Syberii straciły starszych członków rodzin i małe dzieci, z głodu i mrozu. Byli w łachmanach, często nie mieli nawet czajnika, podstawowego dobra tej naszej społeczności.

Na kartki chlebowe nikt z nas nie mógł liczyć, aby je otrzymać, trzeba było się zarejestrować, a taka propiska dla bezpaństwowców nie wchodziła w ogóle w rachubę. Uzbecy dookoła głodowali zresztą również, w olbrzymich rodzinach było po jakiejś jednej owcy czy po kilka kur. Mężczyźni, chłopcy po 17-18 lat byli zgarniani do Armii Czerwonej, nasza gospodyni miała 5 synów na froncie. Polscy żołnierze, mizerne chłopaki po obozowych przejściach i tyfusie, wyfasowali najczęściej zbyt obszerne brytyjskie mundury, które w żaden sposób nie były przewidziane na panujące temperatury ponad 50 stopni w słońcu, warty kończyły się omdleniami, a wody pitnej było wciąż za mało - chłopaki piły nieprzegotowaną i łapały czerwonkę, i wszelkie pasożyty. Wujek Zygmunt i inni lekarze nie nadążali z leczeniem tych biedaków, którzy dotrwali do tej chwili, a żadne apele do przedwojennych kaprali i ich przełożonych nie skutkowały - wojsko Andersa było wojskiem według najlepszej kapralskiej tradycji. Warty z beretem jako ochroną przed słońcem, niekończące się nabożeństwa, święcenie sztandarów i przemówienia wodzów zbierały obfite żniwo - szpital polowy był pełny, chłopcy umierali jak muchy.

Zaraz po naszym przybyciu do Kermine wuj Zygmunt i dr Adam Zyss powiedzieli właściwie chórem: „Nikt nas tu nie chce”. Pamiętam, że pytałam mamę, o jakich nas chodzi, przecież powitano nas konserwami! Z mięsem! Wkrótce zrozumiałam - ojciec zgłosił się kolejny raz, tym razem powiedziano mu wyraźnie, żeby się nie pchał, że mają dość „takich” lekarzy i, w ogóle, że to polskie wojsko. Ale dalej mieliśmy status rodziny wojskowej, co teoretycznie uprawniało nas do jakiegoś przydziału konserw i sucharów. Ale... konserwy w namiotach gospodarczych eksplodowały jak pociski w tym piekielnym klimacie, a suchary? Suchary pojawiły się w odległym miasteczku, na bazarze, personel gospodarczy nie zasypiał gruszek w popiele. Cornedbeef, prostokątna puszka szczęścia, była też do kupienia, jeśli ktoś miał za co.

Głodowaliśmy i chudliśmy. Niedojrzałe, mizerne morele rosnące wzdłuż drogi, wytłoczyny z ziaren bawełny, zwane „żmychem”, pastewna kasza dżugara, a wszystko zapijane tą letnią wodą przegotowaną, skończyło się dla ojca i dla mnie czerwonką. Lekarstwo cuchnące karbolem ukradł dla mnie w wojskowym szpitalu kapitan Zyss, mój wuj był praworządny, więc prosił i dostał odmowę. Do rekonwalescencji potrzebna była kasza - tę rolę pełniły rozmoczone suchary wujka, który cierpiał potwornie z powodu upałów i sam chyba niczego nie jadł. Dla ojca nie wystarczało, on już pod koniec czerwca właściwie wstawał tylko do wygódki. Dziś wydaje się to śmieszne na tle wszystkich innych 
problemów, ale całej ciągle chorej szóstce w tej stajence strasznie dopiekał brak papieru gazetowego do wiadomego użytku - były jakieś uzbeckie drukowane przemówienia, które kroiło się w malusieńkie kawałki, a jeśli były na nich portrety wodzów, to wycinaliśmy je i chowali - a nuż ktoś doniesie, że nie uczciliśmy?

Pani Anka, która była coraz grubsza, w miarę jak inni wysychali, była tak słaba, że tylko przed wejściem do stajenki gotowała tę wodę na zieloną gruzińską herbatę, o której Uzbecy mówili, że leczy wszystkie dolegliwości, a więc był ten czaj „na wagę złota”, czyli kolejnej... konserwy brytyjskiej lub aspiryny. Dorośli bali się o panią Annę, bo wciąż dochodziły plotki o ludożercach, ale niebawem zaczęły z niej wychodzić ohydne różowe glisty, umierałam z obrzydzenia, a ona, upokorzona piękna arystokratka, zapadała się w sobie szybciej niż my.

Moja wysoka mama natomiast nosiła najpierw po pół wiadra wody ze studni, potem ćwierć, zgięta wpół, ale nieugięcie na nogach. Ważyła ze czterdzieści kilka kilo. Przy nieustannych czerwonkach wszystkie szmaty były na śmierć zaprane w mydle wyłudzanym od znajomych lekarzy (a mydło było czasem ważniejsze nawet od żywności, na tych samych listach pomocowych). Kiedy byłam już dużo starsza, pytałam, jak sobie mama i pani Anka radziły przy miesiączce, czy po prostu kradły bawełnę z pola, odległego o dobre 8-10 km, owocującego dopiero we wrześniu. Mama zdziwiła się nawet: „Przecież jak zaczęła się głodówka, to straciłyśmy miesiączkę"...

To Witek i ja byliśmy posyłani do namiotu kuchennego po zupę, sporządzaną z otwartych konserw, która niby należała się wszystkim Polakom zgromadzonym przy jednostkach andersowskich. Braliśmy największe blaszanki po sucharach, z uchem ze sznurka, i maszerowaliśmy jak najwcześniej pod namiot kuchenny. Rozdawanie zaczynano chyba o 12-tej. Od słońca mieliśmy jakieś szmaty na głowie i ustawialiśmy się w długiej kolejce niedożywionych dorosłych i dzieci, mdlejących z upału. Przechodzący podoficerowie podśmiewali się, że znów gudłaje i kacapy stoją, a żołnierze, ci gudłajscy i kacapscy, pomykali, nie patrząc w naszą stronę, a czasami dawali suchary. Klapa namiotu podnosiła się, stawał w wejściu dobrze odżywiony kapral z chochlą i wołał: „Zupa!”. Kolejka karnie posuwała się z menażkami, bańkami, puszkami, kocioł był przy samym wejściu, ale na tyle wysoko, że nie widzieliśmy, ile w nim jeszcze jest. Aż następował moment, kiedy kapral ze złośliwym uśmiechem wołał: „Rzym.-kat. wystąp!”, co kolejka przyjmowała z jękiem i rezygnacją. Najbardziej cierpieli mali Poleszucy, ich polszczyzna nie pozostawiała złudzeń, że są wschodniego obrządku. Żydzi mamrotali przekleństwa pod nosem, a my - głupki z rodzin zasymilowanych - nie zrozumieliśmy za pierwszym razem, o czym jest mowa. Myślałam, że to jakieś kartki, jak na chleb. Minęło ponad 70 lat, a ja widzę przed sobą ten zadowolony pysk i łudzę się nadzieją, że umierał w męczarniach, jak ci nieszczęśnicy koło stacyjki w Kermine, cuchnący ekskrementami, ginący z głodu i czerwonki. Zresztą system szedł z góry, on z lubością dbał tylko o wykonanie, ale to doszło do mnie dużo, dużo później. 
Na razie wojsko ćwiczyło. Na komendę: „Kompania śpiewa” śpiewało Serce w plecaku i Jak to na wojence ładnie, maszerując w pełnym wełnianym rynsztunku. Biedni połagrowi chłopcy, którzy wydostali się z syberyjskich mrozów, nie zdawali sobie sprawy, czym grozi subtropikalna pustynia, zawijali głowy mokrymi ręcznikami, które schły błyskawicznie i powodowały ciężkie udary mózgowe. Lekarze wojskowi, sami ledwo żywi, walczyli z niewiedzą, wszami, świerzbem, czyrakami i powszechną czerwonką, a malaria dołączyła dla tych, którzy przebywali w miasteczku, bliżej nawadnianych pól bawełnianych.

Co jakiś czas odbywały się wieczorne spędy, niezmiennie połączone z mszą świętą, zwłaszcza kiedy zawitał biskup [Józef] Gawlina. Razem z gen. [Leopoldem] Okulickim spacerowali między zgromadzonymi, biskup błogosławił i rozdawał święte obrazki, dzieci spodziewały się cukierków, których nie było. Był też, a jakże, hufiec junacki, który śpiewał: „Czy umrzeć nam przyjdzie w boju, czy w tajgach Sybiru nam gnić, z trudu naszego i znooooju Polska powstanie, by żyć" i było podniośle, i moje dorosłe głodomory ocierały łzy wzruszenia. Nie wiem, czy dywizja w swoim składzie posiadała jakiegoś prawosławnego czy unickiego kapelana, wschodniacy byli dyskryminowani tak samo jak Żydzi, a rabina to już na pewno nie było. Generała Andersa nie widziałam ani razu. Znajomi oficerowie bali się Okulickiego, był arogancki i wyniosły, karał za niedokładności w umundurowaniu, ignorował skargi na skalę złodziejstwa leków i żywności.

Było coraz głodniej, na wymianę nie było już niczego, pani Anka sprzedała ostatni pierścionek i płaciła za nas „komorne”, rublami można było płacić tylko za gazety i, o dziwo, naftę do kaganków. Uzbecy rubli właściwie nie brali. Na froncie Niemcy doszli do Wołgi, a do stacji Kermine maszerowały kolumny uzbeckich chłopców w szmacianych butach i nędznych mundurach. Wszystko dla zwycięstwa - „Wsio dlia pobiedy” - jak mówiły napisy na każdym wagonie. Matki nie odprowadzały synów, później zastanawialiśmy się, że chyba bały się płakać przy konwojencie - terror lat trzydziestych był tam namacalny.

Ciągle opóźniał się transport do Teheranu, a plotka straszyła, że najpierw zdechniemy z głodu, a ci, co przetrwają, zostaną wcieleni do strojbatalionów. Takie bataliony budowaŁy pospiesznie fabryki do montażu amerykańskiej broni i transporterów, elektrownie np. w Ferganie dla przemysłu zbrojeniowego, a dwunastogodzinna praca niemal bez wyżywienia uśmiercała w ciągu miesiąca. Kiedy wydawało się, że się spełnią najgorsze oczekiwania, pojawił się oficjalny komunikat na namiocie kuchennym, że będzie transport, że będzie dość wagonów towarowych (jakby ktoś się innych spodziewał...), że polscy obywatele mają się zarejestrować, że najprawdopodobniej wyjazd będzie 6 sierpnia, no i coś tam o przepisach sanitarnych, może o odwszeniu, nie pamiętam. Co ciekawe, nigdzie nie zdołałam dokładnego sformułowania znaleźć. Dla ludzi ze wschodnich terenów, które stały się Zachodnią Ukrainą czy Białorusią, był to przełom. Oni bali się najbardziej przymusowego przyjęcia paszportu radzieckiego. Jak się niebawem okazało, ich radość była przedwczesna. Ludzie oszaleli z radości. Ci, co nie wstawali od dawna, zebrali siły i podążyli do miasteczka, żeby się zgłosić. Mama, krakowianka z tradycjami, skomentowała datę: „Cóż, ruszamy jak pierwsza kadrowa z Oleandrów”. 
Podstawiono pociąg, pierwsze wagony miały mieścić dowództwo i sztab, dalej żołnierzy, a na końcu szeroko pojęte rodziny wojskowe. Ustawiliśmy się wszyscy przy wagonach, czekając na przydział miejsca. Zupak, strzegący wejścia zapytał: „A co ja będę z tego miał?”. „Jak to, my do transportu...” „Taki naród handlowy, a nie ma bodaj obrączek?”. „Przejedzone, panie kapralu”. Obok nas ustawili się tacy, co jeszcze coś mieli, jakieś złote ruble, dla nich wrota wagonu się otworzyły... Rodzice i państwo Zyssowie, nieprzytomni ze zdenerwowania, usiłowali się porozumieć z naszymi dwoma lekarzami w miasteczku. Przyjechał ciężarówką wojskową ze sprzętem szpitalnym wujek Zygmunt, próbował coś rozkazać podoficerom pilnującym pociągu, naraził się na kpiny. Postanowił natychmiast udać się do sztabu, gdzie miał bardzo dobrą opinię jako lekarz i zrobić awanturę, co było absolutnie przeciwne jego naturze. Zmęczony, schorowany, w piekielnym grubym mundurze, czuł się bardzo źle, tylko rychłe spotkanie z żoną i córką w Teheranie trzymało go na nogach. Zatrzymał jakąś ciężarówkę, podciągał się do środka przez podniesioną tylną klapę i spadł. Złamał podstawę czaszki, umarł po godzinie. Nie udało się ustalić, czy to kierowca ruszył, czy wuj stracił przytomność - było to już bez znaczenia. Następnego dnia, kiedy pociąg z pustymi wagonami rodzinnymi w składzie odjeżdżał do Teheranu, my chowaliśmy wuja kapitana Zygmunta Weindlinga na małym wojskowym cmentarzu, gdzie przy wejściu widniał napis:

Niech nikt nad grobem tym nie płacze,

Niech nikt nie szlocha skargi słowem,

Uwięzion tylko proch tułaczy -

Duch tworzy z nami Polskę nową.

Mała grupka na cmentarzu była przekonana, że niebawem również zamieni się w proch tułaczy.

Z danych znalezionych w Internecie (Patlewicz, 2007) wynika, że generał Anders wyjechał do Teheranu 19 sierpnia 1942 roku. Czy generał Okulicki wyjechał z Kermine wraz ze swą dywizją 6 sierpnia, nie wiem, tego dzieci nie rejestrują, tak jak rozpaczy rodziców i umierania dokoła. Tak czy owak, nieprawdopodobne, aby wysoka generalicja nie dostrzegła tego, co się działo pod jej dowództwem. Nota bene, w cytowanej pracy mowa jest o podziale na ludność polską i na grupy narodowościowe. Błąd moich rodziców, naszych przyjaciół i wielu innych z tego grona polegał na głębokim przekonaniu, że jesteśmy Polakami wyznania mojżeszowego - tak się to wtedy nazywało - że nie stanowimy osobnej narodowości. Stanie przy pociągu, który dla mniejszości okazał się dostępny tylko za sowitą opłatą, choć alternatywą mogła być śmierć, stało się znakomitym zabiegiem terapeutycznym...

Kiedy już po Stalingradzie w Kermine wreszcie zorganizowano jakąś polską niby-szkołę dla nastolatków, kiedy nabraliśmy zaufania do pana Katza (oczywistego pochodzenia), który uczył nas polskiego, jeden z chłopaków, genialnie naśladując wymowę junaków, zapytał: „No dobrze, a jak przendziem Dniestr i przendziem Bug, to bendziem Polakami?”. Pan Katz, który również nie zmieścił się w transporcie do Teheranu, odpowiedział 
z przekonaniem: „O-czy-wiś-cie. A teraz nie nudźcie, tylko bierzcie się do czytania”. Był to chyba Bartek Zwycięzca, wydany przez polską Delegaturę Rządu na Związek Radziecki. Delegatura skończyła się wkrótce po odjeździe armii Andersa do Persji. Stalinowi się kolejny raz odmieniło i przedstawiciele londyńscy z Kujbyszewa i innych placówek dostali wieloletnie wyroki.

Cóż, pozostaje dokończyć wątki, ażeby wypełnić lukę od sierpnia do grudnia tego niezapomnianego roku. Magazyny wojskowe zostały przekazane Rosjanom, stali przy namiotach jacyś bezpieczniacy, którzy z radością przyjęli wódkę, wraz z udziałem w „łupie”. Niedobitki afery pociągowej rzuciły się na konserwy, koce, płachty brezentowe, swetry i skarpety, a przede wszystkim buty. Szatański wynalazek armii brytyjskiej, sztylpy ze sztywnego brezentu okazały się cudownym surowcem na podeszwy sandałów. W płaszczu z koca, jak również w butach numer 41, z gazetą w czubkach, chodziłam aż do 1946 roku, do powrotu do Polski.

W miejscowym szpitalu nie było żadnej wykwalifikowanej siły, wszyscy poszli na front, więc ojca późną jesienią zatrudniono jako lekarza. Chyba w 1943 roku, już po zwycięstwie stalingradzkim, dostaliśmy kartki chlebowe, co prawda chleba na nie najczęściej nie było. Najgorzej skończyło się dla Polaków urodzonych na wschód od Bugu, wmuszono im radzieckie paszporty i odcięto w ten sposób szansę na repatriację po wojnie. Nadal było głodno, ale ojcu czasami po cichu płacono jajkami lub baraniną, kiedy chodził do pacjenta w środku nocy. Żywiliśmy się też żółwiami, które wędrowały przez pustynię od rzeki Zarawszan - Uzbecy uważali je za nieczyste, a my za rzadki delikates...

O losach armii Andersa dowiedzieliśmy się dopiero po wojnie, informacja sowiecka dotyczyła wyłącznie zwycięstw radzieckich, a korespondencja z zagranicą praktycznie nie istniała.

Wróciliśmy w 1946 roku do Polski i, jak w tym epitafium, tworzyliśmy Polskę nową. Rodzice podjęli pracę lekarzy, pan Bernard Zyss tworzył od nowa polski przemysł chemiczny. Krótko mówiąc, jak zalecał Wolterowski Kandyd, milczeliśmy i uprawialiśmy swój ogródek. Z jakże różnym skutkiem...

\section{Bibliografia}

Patlewicz, B. (2007). Ludność cywilna i sieroty polskie po amnestii 12 sierpnia 1941. Zesłaniec. Organ Rady Naukowej Związku Sybiraków, 32, 71-84. 


\section{The unforgotten 1942}

Abstract: Ewa Weinberg relates her story of the deportations of Polish citizens to the USSR in the summer of 1940 and their life in 1942. After the Sikorski-Majski Pact had been signed and Anders's Army established, the deportees tried to leave Siberia for Samarkand, Uzbekistan. In Samarkand, it turned out that the category of citizenship is no more valid for the deportees: anti-Semitic acts were very common, but the persecutions were also applied to non-Roman Catholic Christians. Such behaviour was legitimate from the point of view of the majority and their model of society. When trying to get onto the train to Tehran, Weinberg's friends and relatives (members of the Polish intelligentsia) heard a question: "You're a nation of merchants and you do not even have a golden ring?". In consequence, some of the cars left empty, having left stranded some Polish citizens categorised as gudłaje $i$ kacapy (contemptuously: Jews and Russians).

Keywords: Soviet deportations, Siberia, Samarkand, Tehran, Anders's Army (7 $7^{\text {th }}$ Division), anti-Semitism, exclusion, discrimination, bishop Józef Gawlina, Leopold Okulicki, the Weinberg family, the Weindling family, the Zyss family, Poleszuks 